R. Ogórek, M. Dyląg, B. Kozak, Z. Višňovská, D. Tančinová, and A. Lejman - Fungi isolated and quantified from bat guano and air in Harmanecká and Driny Caves (Slovakia). Journal of Cave and Karst Studies, v. 78, no. 1, p. 41-49. DOI: 10.4311/2015MB0108

\title{
FUNGI ISOLATED AND QUANTIFIED FROM BAT GUANO AND AIR IN HARMANECKÁ AND DRINY CAVES (SLOVAKIA)
}

\author{
Rafą OGórek'*, Mariusz DyląG', Bartosz KozaK², Zuzana Višňovská3, \\ Dana Tančinová4, And Agnieszka Lejman ${ }^{5}$
}

\begin{abstract}
This study is the first mycological evaluation of bat guano and the air around it in Harmanecká and Driny Caves in Slovakia. These caves are the most important underground localities of bats in Slovakia. Samples were collected in July 2014 and cultivated for fungi. Harmanecká Cave had seven species of filamentous fungi and one yeast-like fungus isolated from bat guano, compared to six species of filamentous fungi in guano from Driny Cave. Air samples from Harmanecká Cave had twelve species of fungi, compared to nine species from Driny Cave. Fungal density was higher in guano from Driny Cave (4720.1 CFU/g guano) than from Harmanecká Cave (3498.3 CFU/g). The pattern was reversed with fungi from the air. Fungal density in air from Harmanecká Cave $\left(211.3 \mathrm{CFU} / \mathrm{m}^{3}\right)$ was higher than that from Driny Cave $\left(175.7 \mathrm{CFU} / \mathrm{m}^{3}\right)$. Penicillium granulatum was the most frequently isolated fungal species, except in the guano of Driny Cave, where Mucor hiemalis was most common. Bat guano is a very good substrate for the development and survival of fungi in the caves, and it can be a reservoir of fungi harmful for bats. However, air samples from both caves contained more species of fungi than the bat guano, because the majority of fungi are transferred to underground ecosystems with air bioaerosols from the external environment.
\end{abstract}

\section{INTRODUCTION}

Cave ecosystems and other underground habitats are characterized by low temperatures and low availability of nutrients (Ogórek et al., 2013). Bat guano is rich in carbon, nitrogen, and vital minerals, so it is used in agriculture for fertilization of plants (Shetty et al., 2013). Bat guano, plant debris, animal carcasses, and other organic debris are the most important substrates for fungi inside caves (NievesRivera et al., 2009).

Fungal conidia or spores are commonly found in caves and other underground environments. These elements enter mainly with air currents from the external environment (Pusz et al., 2014; Ogórek et al., 2014a, 2014b, 2014c). They can also be carried into caves by water, by animals such as bats and arthropods, or by humans visiting underground spaces (Mulec, 2008; Chelius et al., 2009; Vanderwolf et al., 2013; Griffin et al., 2014). The cave mycobiota are very important for underground ecology, because the fungi present are decomposers or parasites and probably constitute the major food source for other organisms (Sustr et al., 2005; Walochnik and Mulec, 2009; Bastian et al., 2010). Evidence for microbial activity in a cave includes spots on the cave surfaces, unusual coloration of speleothems, precipitates, corrosion residues, structural changes, and the presence of biofilms (Barton, 2006).

Bats are mammals that lead nocturnal lives and play important roles in the ecosystem such as plant pollination, seed dissemination, forest regeneration, and insect control, so their health and factors that influence it should be of high concern. Investigating fungi in guano is appealing, because guano is found in the immediate neighborhood of bat roosts and is likely to be highly exposed to bat pathogens. Bat pathogens probably won't grow on guano, but can land on it. Moreover, sampling of guano is noninvasive, in contrast to direct examination of bats, and may be conducted at a time when bats are absent from their hibernacula (Mulec, 2008; Nováková, 2009).

Harmanecká and Driny Caves rank among the most important underground localities for bats in Slovakia. The dominant species in Harmanecká Cave are the greater mouse-eared bat (Myotis myotis) and the lesser mouseeared bat (M. blythii), with 1000 to 1500 hibernating individuals. The dominant species in Driny Cave is the lesser horseshoe bat (Rhinolophus hipposideros), with 100 to 150 individuals (Lehotská and Lehotský, 2009).

Our research focused on two goals, the mycological analysis of the species composition of the fungi found in

\footnotetext{
${ }^{1}$ University of Wroclaw, Institute of Genetics and Microbiology, Department of Genetics, Przybyszewskiego Street 63/77, 51-148 Wroclaw, Poland

${ }^{2}$ Wroclaw University of Environmental and Life Sciences, Department of Genetics, Plant Breeding and Seed Production, Grunwaldzki Square 24a, 50-363 Wroclaw, Poland

${ }^{3}$ State Nature Conservancy of the Slovak Republic, Slovak Caves Administration, Hodžova 11, 031-01 Liptovský Mikuláš, Slovakia

${ }^{4}$ Slovak University of Agriculture in Nitra, Department of Microbiology, Tr. Hlinku 2, 949-76 Nitra, Slovakia

${ }^{5}$ Department of Agroecosystems and Green Areas Management, Wrocław University of Environmental and Life Sciences, Grunwaldzki Square 24a, 53-363 Wrocław, Poland

*Corresponding author: rafal-ogorek@wp.pl
} 
the guano of bats and airborne fungi around it in the Harmanecká and Driny Caves and the quantification of their concentrations.

\section{Materials AND Methods}

Harmanecká Cave is located in the Harmanec Valley to the northwest of Banská Bystrica city, in the southern part of the Great Fatra Mountains. Geographic coordinates of the cave are $8^{\circ} 81^{\prime} 39^{\prime \prime} \mathrm{N}, 19^{\circ} 04^{\prime} 01^{\prime \prime} \mathrm{E}$. Its entrance is situated on the northern side of Kotolnica Hill at $821 \mathrm{~m}$ a.s.l. Its length is $3123 \mathrm{~m}$, and the length of the tourist path is $1020 \mathrm{~m}$. The cave was discovered in 1932 by Bacúrik, and it was opened to the public in 1950. During World War II, the cave served as a shelter for local people (Bella et al., 2001; Lehotská et al., 2011). The air temperature in the cave is between 5.8 and $6.4{ }^{\circ} \mathrm{C}$, and the relative humidity is between 94 and $97 \%$ (Bella et al., 2001). Driny Cave is located in the Smolenice Karst in the Lesser Carpathian Mountains, south-west from Smolenice, in the Trnava district and near the recreation resort Jahodník. Geographic coordinates of the cave are $48^{\circ} 50^{\prime} 04^{\prime \prime} \mathrm{N}, 17^{\circ} 40^{\prime} 20^{\prime \prime} \mathrm{E}$. Its entrance is situated on the western slope of Driny Hill at 399 m a.s.l. and its length is $680 \mathrm{~m}$. The cave was discovered in 1929 by Vajsábel and Banič, and it was opened to the public in 1935 with provisional electric lighting for 175 meters. Now the length of the tourist path is $410 \mathrm{~m}$ (Bella et al., 2001; Lehotská et al., 2011). The air temperature in the cave is between 7.1 and $7.8{ }^{\circ} \mathrm{C}$, and the relative humidity is between 92 and $97 \%$ (Bella et al., 2001). In 2014, Harmanecká Cave was visited by 17,425 people, and Driny Cave was visited by 31,859 people.

The samples were taken on July 24, 2014 from Harmanecká Cave and on July 25, 2014 from Driny Cave, before tourists arrived. Bat guano, not fresh, was found only in a single location in Harmanecká Cave, in the Entrance Dome in front of an airlock door, and also only in a single location in Driny Cave, about $140 \mathrm{~m}$ into the cave in the Slovak Speleological Society Hall (Fig. 1). The guano samples were collected using sterile forceps and placed into sterile sampling bags (three samples per cave, about $8 \mathrm{~g}$ of guano per sample). The samples were transported in cool conditions (ca. $7{ }^{\circ} \mathrm{C}$ ) to the laboratory and were stored there in the cold room. Mycological evaluation of the samples was carried out within three days from the date of sampling. The air samples were collected using an Air Ideal 3P sampler and Potato Dextrose Agar (PDA) medium. It was programmed for air sample volumes of $50 \mathrm{~L}, 100 \mathrm{~L}$, and $150 \mathrm{~L}$. Measurements in several locations around each guano pile were performed in three replicates for each volume. The sampler was positioned about $1.5 \mathrm{~m}$ from the bat guano.

Potato Dextrose Agar (PDA, Biocorp) was used for the isolation of fungi from the guano and from the air and for the identification of some species. Czapek-Dox Agar (1.2\%

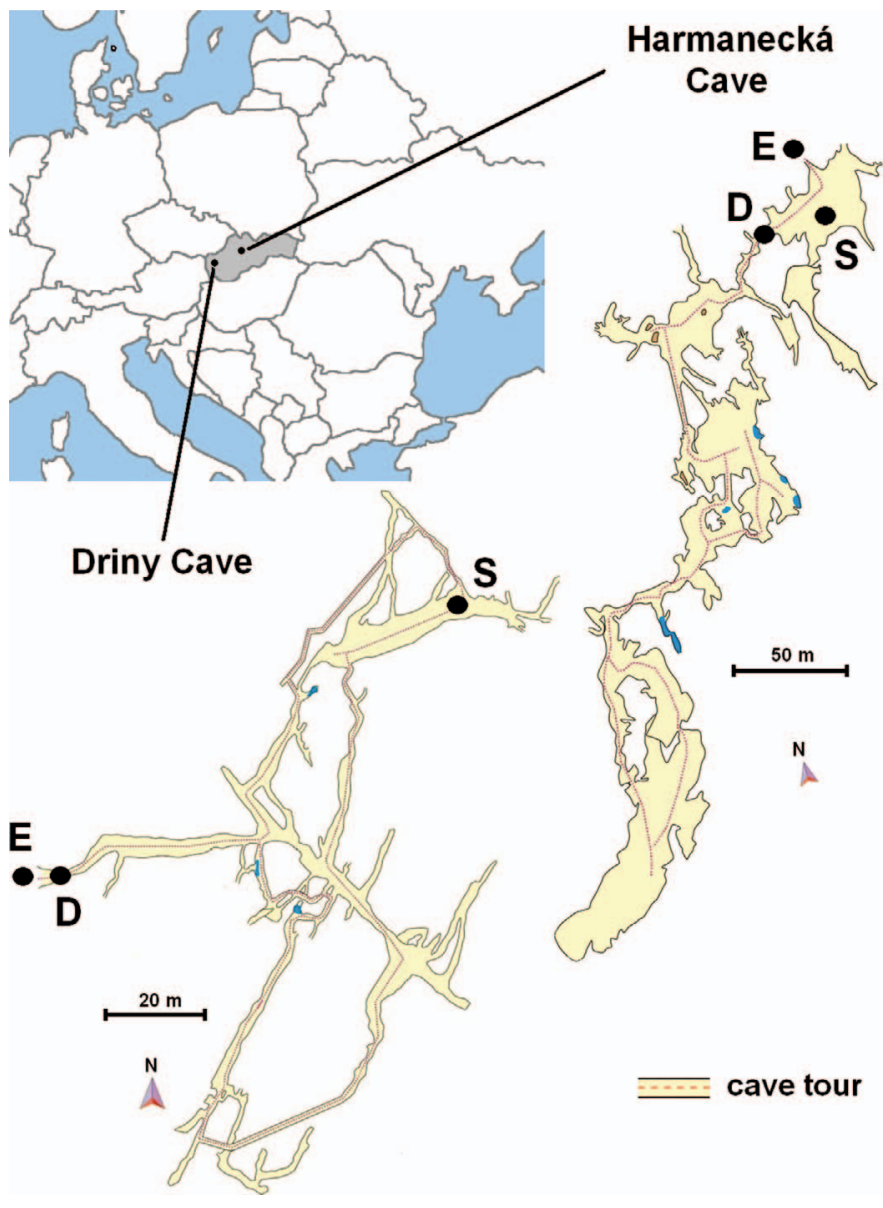

Figure 1. Geographic location of the caves and map of the tourist routes: $\mathrm{E}$ - entrance and exit of the cave; D - airlock door; S - sampling locations (Harmanecká Cave, before the airlock door in the Entrance Dome; Driny Cave, about 140 m into the cave, in the Slovak Speleological Society Hall).

agar, Biocorp) and Malt Extract Agar (MEA, Biocorp) were used for the identification of species belonging to the Penicillium and Aspergillus genera. Sabouraud Agar ( $4 \%$ dextrose, $2 \%$ agar, $1 \%$ peptone, A\&A Biotechnology) medium was used for identification of yeast-like fungi.

One gram of guano (in three replicates) taken from each sample was shaken for 20 minutes in a $250-\mathrm{mL}$ Erlenmeyer flask containing $9 \mathrm{~mL}$ of sterile distilled water. After shaking, samples were spread-plated using serial dilution onto PDA. Incubation was carried out at 15,20 , and $25^{\circ} \mathrm{C}$ for 4 to 14 days in the dark. After incubation, the number of colonyforming units (CFU) per $1 \mathrm{~g}$ of guano was calculated as averages from the replicates at all incubation temperatures.

Similarly, the incubation of cultures from the air samples on PDA was carried out at 15,20 , and $25{ }^{\circ} \mathrm{C}$ for 4 to 14 days in the dark. After incubation, the number of CFU per $\mathrm{m}^{3}$ of air was calculated as averages from the replicates at all incubation temperatures.

After incubation, the fungal colonies grown were counted and identified. The species identification was 
Table 1. Filamentous and yeast-like fungi cultured from the bat guano and the air around it in the Harmanecká and Driny Caves. A + indicates that the species was found.

\begin{tabular}{|c|c|c|c|c|}
\hline \multirow[b]{2}{*}{ Fungi Species } & \multicolumn{2}{|c|}{ Harmanecká } & \multicolumn{2}{|c|}{ Driny } \\
\hline & Guano & Air & Guano & Air \\
\hline Absidia glauca Hagem & + & + & & \\
\hline Alternaria alternata (Fr.) Keissl. & & & & + \\
\hline Aspergillus foetidus Thom \& Raper & + & + & + & \\
\hline Aspergillus fumigatus Fresen. & & & + & + \\
\hline Botrytis cinerea Pers. ex. Fr. & & + & & \\
\hline Cladosporium herbarum (Pers.) Link & & + & & + \\
\hline Epicoccum nigrum Link & & + & & + \\
\hline Gliocladium roseum Bainier & & + & & \\
\hline Mucor hiemalis Wehmer & + & + & + & + \\
\hline Penicillium chrysogenum Thom & + & + & + & + \\
\hline Penicillium granulatum Rainier & + & + & + & + \\
\hline Penicillium lanosocoeruleum Thom & & + & & \\
\hline Penicillium roseopurpureum Dierckx & + & & & \\
\hline Penicillium urticae Bainier & & + & & + \\
\hline Phoma fimeti Brunaud & & & & + \\
\hline Rhizopus stolonifer (Ehrenb.) Vuill. & + & + & + & \\
\hline Rhodotorula glutinis (Fresen.) F.C. Harrison & + & & & \\
\hline$\sum$ species & 8 & 12 & 6 & 9 \\
\hline
\end{tabular}

performed using macro- and microscopic observations, namely the morphology of hyphae, conidia, or spores and the colonies that had grown on culture media. The filamentous fungi were identified using diagnostic keys and descriptions by Pitt and Hocking (2009) and Watanabe (2010). The yeast-like fungi were identified using the diagnostic key and descriptions by Kurtzman and Fell (1998).

\section{RESULTS}

The bat guano and the air around it in Harmanecká Cave contained more species of fungi than the samples from Driny Cave. Seven species of filamentous fungi and one of the yeast-like group of fungi were isolated from the guano of Harmanecká Cave and six species of filamentous fungi from Driny Cave. Air samples from Harmanecká Cave grew twelve species of filamentous fungi, and there were nine species from Driny Cave air. Penicillium roseopurpureum and Rhodotorula glutinis were isolated only from the guano sampled, whereas Alternaria alternata, Botrytis cinerea, Cladosporium herbarum, Epicoccum nigrum, Gliocladium roseum, Penicillium lanosocoeruleum, Penicillium urticae, and Phoma fimeti were found exclusively in the samples of air (Table 1).

The largest group of filamentous fungi in both caves constituted fungi of the genus Penicillium, whereas the yeast-like fungi were cultured only from guano sampled from Harmanecká Cave. The concentration of all fungi isolated from bat guano was 3498.3 colony-forming units per $1 \mathrm{~g}$ of guano from Harmanecká Cave and 4720.1 per
$1 \mathrm{~g}$ of guano from Driny Cave. Air samples respectively grew 211.3 and 175.7 CFU per $1 \mathrm{~m}^{3}$ of air (Tables 2 and 3).

Of the colonies cultured from guano, $75 \%$ from Harmanecká Cave were Penicillium granulatum and 54\% from Driny Cave were Mucor hiemalis (Figs. 2 and 3). Fungal species such as Absidia glauca, $P$. roseopurpureum and $R$. glutinis were isolated only from the guano collected in Harmanecká Cave and Aspergillus fumigatus only from Driny Cave (Table 1).

The fungus most frequently cultured from the air was $P$. granulatum (Fig. 4) in both caves, and it constituted approximately $45 \%$ of fungi (Table 3, Figs. 2 and 3). $A$. alternate, A. fumigatus and $P$. fimeti were present only in the air of Driny Cave, whereas A. glauca, Aspergillus foetidus, B. cinerea, G. roseum, P. lanosocoeruleum, and Rhizopus stolonifer were found exclusively in the air of Harmanecká Cave (Table 1).

The air samples in both the caves contain both quantitatively and qualitatively more propagules of fungi than the bat guano. $P$. granulatum was the most frequently isolated fungus with the exception of the guano collected in Driny Cave, where M. hiemalis was the most common (Fig. 2 and 3).

\section{DisCUSSION}

The most important factors affecting the survival of fungi in the environment are temperature and humidity. However, underground environments are characterized by a very specific, stable microclimate; therefore the most important factors that determine occurrence of fungi in

Journal of Cave and Karst Studies, April 2016•43 
Table 2. Mean concentrations of filamentous and yeast-like fungi cultured from the bat guano collected in the Harmanecká and Driny Caves

\begin{tabular}{|c|c|c|c|c|}
\hline \multirow[b]{3}{*}{ Cave } & \multirow[b]{3}{*}{ Fungi Species } & \multicolumn{3}{|c|}{ Guano (CFU/g) } \\
\hline & & \multicolumn{2}{|c|}{ Individual Species } & \multirow[b]{2}{*}{ Total } \\
\hline & & Range of Values & Mean $\pm \mathrm{SD}^{\mathrm{a}}$ & \\
\hline \multirow[t]{9}{*}{ Harmanecká } & & & & 3498.3 \\
\hline & Absidia glauca & $71.0-185.0$ & $133.2 \pm 44.3$ & \\
\hline & Aspergillus foetidus & $45.0-135.0$ & $94.7 \pm 34.4$ & \\
\hline & Mucor hiemalis & $133.0-297.0$ & $225.8 \pm 56.1$ & \\
\hline & Penicillium chrysogenum & $103.0-244.0$ & $180.5 \pm 56.1$ & \\
\hline & Penicillium granulatum & $1521.0-3810.0$ & $2644.0 \pm 879.3$ & \\
\hline & Penicillium roseopurpureum & $42.0-115.0$ & $79.8 \pm 26.8$ & \\
\hline & Rhizopus stolonifer & $60.0-181.0$ & $120.3 \pm 44.8$ & \\
\hline & Rhodotorula glutinis & $2.0-40.0$ & $20.0 \pm 14.2$ & \\
\hline \multirow[t]{7}{*}{ Driny } & & & & 4720.1 \\
\hline & Aspergillus foetidus & $14.0-40.0$ & $25.0 \pm 10.1$ & \\
\hline & Aspergillus fumigatus & $21.0-74.0$ & $50.3 \pm 20.9$ & \\
\hline & Mucor hiemalis & $1500.0-3800.0$ & $2550.1 \pm 869.7$ & \\
\hline & Penicillium chrysogenum & $146.0-339.0$ & $249.4 \pm 78.2$ & \\
\hline & Penicillium granulatum & $1026.0-2679.0$ & $1825.0 \pm 598.0$ & \\
\hline & Rhizopus stolonifer & $8.0-34.0$ & $20.3 \pm 9.6$ & \\
\hline
\end{tabular}

${ }^{\mathrm{a}} \mathrm{SD}=$ Standard Deviation

them are airflow, the conditions prevailing in the neighboring external environment, such as the season, local flora, the geographical location, and especially the availability of organic matter (Ogórek et al. 2013, 2014a, 2014b; Pusz et al. 2014; Vanderwolf et al. 2013). In our study, the most species of fungi were isolated from Harmanecká Cave. The situation is probably because the samples were taken in Harmanecká Cave between the entrance and the air-lock door and in Driny Cave behind the door, so the samples in Harmanecká Cave were directly exposed to airborne fungi from the surrounding external environment.

The traditional assessment method for fungi based on the calculation of colony-forming units and microscopic analysis, which is more common and cheaper than molecular biological methods, gives the ability to identify colonies to the species level, and a huge reference database is available for the proper identification of strains (Pasanen 2001; Rastogi and Sani, 2011). However, several disadvantages of CFU analysis are also apparent in comparison to molecular methods. CFU analysis does not allow us to detect non-culturable fungi, and also it can overlook fungal species that are not easily culturable. Furthermore, it might underrepresent those fungal types that grow slowly because they are overtaken by faster growing colonies (MacNeil et al., 1995; Wu et al., 2000; Macher, 2001; Pasanen, 2001). In addition, the type of culture medium and temperature of incubation have an influence on the in vitro growth rate of fungi isolated from the environment, their species composition, and their concentrations (Kaufman et al., 1963; Marshall et al., 1998; Meletiadis et al., 2001; Ogórek et al., 2011a, 2011b). A variety of molecular methods based on direct isolation and analysis of nucleic acids or proteins from environmental samples could be a very good alternative to standard culture techniques for in-depth characterization of environmental microbial communities (Rastogi and Sani, 2011).

Littman (1947) reported that Sabouraud Agar medium is the most suitable for isolation of a large spectrum of fungal species from the environment. According to Ogórek et al. (2011a, 2011b), Potato Dextrose Agar medium demonstrates comparable efficacy. Therefore we used this medium for isolation of fungi from the guano and the air samples. Fungal response to temperature is quite varied. Active growth will usually be associated with a limited range of temperatures. However, many fungi remain alive for extended periods at temperatures unsuitable for growth (Smith, 1988). Generally, most fungi grow well at room temperature ranging from 20 to $25{ }^{\circ} \mathrm{C}$, but, for example, the optimal temperatures for growth of Geomyces destructans (now Pseudogymnoascus destructans) is between 12.5 and $15.8{ }^{\circ} \mathrm{C}$, and the upper critical temperature for growth is between 19.0 and $19.8{ }^{\circ} \mathrm{C}$ (Kaufman et al., 1963; Verant et al., 2012). This fungus causes white-nose syndrome in bats (Gargas et al., 2009; Minnis and Lindner, 2013). This is a widespread, epizootic disease affecting hibernating bats, and this disease is associated, inter alia, with an unprecedented bat mortality in the United States and Canada (Blehert et al., 2009). Therefore, we took into account incubation at different temperatures to obtain a wide spectrum of species of fungi. 
Table 3. Mean concentrations of filamentous fungi cultured from the air around the bat guano collected in the Harmanecká and Driny Caves.

\begin{tabular}{|c|c|c|c|c|}
\hline \multirow[b]{3}{*}{ Cave } & \multirow[b]{3}{*}{ Fungi Species } & \multicolumn{3}{|c|}{ Air $\left(\mathrm{CFU} / \mathrm{m}^{3}\right)$} \\
\hline & & \multicolumn{2}{|c|}{ Individual Species } & \multirow[b]{2}{*}{ Total } \\
\hline & & Range of Values & Mean $\pm \mathrm{SD}^{\mathrm{a}}$ & \\
\hline \multirow[t]{13}{*}{ Harmanecká } & & & & 211.3 \\
\hline & Absidia glauca & $4.0-10.0$ & $6.7 \pm 2.2$ & \\
\hline & Aspergillus foetidus & $1.0-3.0$ & $2.1 \pm 0.8$ & \\
\hline & Botrytis cinerea & $7.0-16.0$ & $11.8 \pm 3.0$ & \\
\hline & Cladosporium herbarum & $8.0-19.0$ & $13.1 \pm 3.6$ & \\
\hline & Epicoccum nigrum & $0.0-3.0$ & $1.8 \pm 1.1$ & \\
\hline & Gliocladium roseum & $1.0-3.0$ & $2.1 \pm 0.9$ & \\
\hline & Mucor hiemalis & $7.0-33.0$ & $20.1 \pm 9.5$ & \\
\hline & Penicillium chrysogenum & $9.0-26.0$ & $18.3 \pm 6.2$ & \\
\hline & Penicillium granulatum & $49.0-139.0$ & $96.2 \pm 33.4$ & \\
\hline & Penicillium lanosocoeruleum & $5.0-12.0$ & $8.9 \pm 2.1$ & \\
\hline & Penicillium urticae & $7.0-17.0$ & $11.5 \pm 3.5$ & \\
\hline & Rhizopus stolonifer & $9.0-27.0$ & $18.7 \pm 6.5$ & \\
\hline \multirow[t]{10}{*}{ Driny } & & & & 175.7 \\
\hline & Alternaria alternata & $1.0-3.0$ & $1.9 \pm 0.9$ & \\
\hline & Aspergillus fumigatus & $4.0-10.0$ & $6.8 \pm 2.0$ & \\
\hline & Cladosporium herbarum & $7.0-13.0$ & $10.1 \pm 1.9$ & \\
\hline & Epicoccum nigrum & $2.0-9.0$ & $5.2 \pm 2.7$ & \\
\hline & Mucor hiemalis & $29.0-88.0$ & $59.1 \pm 23.1$ & \\
\hline & Penicillium chrysogenum & $7.0-12.0$ & $8.9 \pm 1.9$ & \\
\hline & Penicillium granulatum & $44.0-115.0$ & $82.2 \pm 28.7$ & \\
\hline & Penicillium urticae & $0.0-3.0$ & $1.3 \pm 1.3$ & \\
\hline & Phoma fimeti & $0.0-1.0$ & $0.2 \pm 0.4$ & \\
\hline
\end{tabular}

${ }^{\mathrm{a}} \mathrm{SD}=$ Standard Deviation.

Bat guano is one of the most important energy inputs for caves in temperate climate zones for survival and development of fungi (Poulson and Lavoie, 2000). Our results agree with those previously described, because mostly the same species of fungi were isolated from both the guano and the air samples, especially Penicillium granulatum, which predominated (Fig. 4, Table 2).

We isolated more fungal species from the air than from the guano. This agrees with other reports that the most species of fungi were isolated from the air samples in underground sites (Ogórek et al., 2013, 2014a; Pusz et al., 2014). Fungi are transferred to mines, adits, and caves by airflow from the external environment, so the majority of fungal species are in the air. The overall mean concentrations of $\mathrm{CFU}$ found in the caves in the present study, 175.7 and $211.3 \mathrm{CFU} / \mathrm{m}^{3}$, were similar to, or lower than, those observed by other studies inside underground enclosures or caves. For example, Ogórek et al. (2014c) isolated from 245.5 to 1040.3 CFU of fungi in $1 \mathrm{~m}^{3}$ of air from the underground Rzeczka complex, and Pusz et al. (2014) collected from 92 to 259 CFU from the underground Osówka complex, while Ogórek et al. (2013) isolated a maximum of only 232 CFU from
Niedźwiedzia Cave. The concentration of airborne fungi in the caves Harmanecká and Driny did not exceed official limits and norms for a health risk to tourists. According to the World Health Organization, air is not too contaminated unless it contains more than 1500 CFU of a mixture of species of fungi in $1 \mathrm{~m}^{3}$ of air (World Health Organization, 1990).

According to Nováková (2009), the largest group of filamentous fungi isolated from bat guano constituted fungi of the genus Penicillium. We obtained similar results. In addition, we isolated filamentous fungi, such as Absidia glauca, Aspergillus spp., Mucor hiemalis, and Rhizopus stolonifer and one species from the yeast-like group, Rhodotorula glutinis. According to other researchers, bat guano is also a reservoir of fungi that may be dangerous for mammal health such as Candida spp., Geomyces spp., Microsporum spp. Trichosporon spp., and Trichophyton spp. (Nováková, 2009; Mulec et al., 2013). In our studies, we did not detect any of the above fungi in the bat guano. Especially important is the absence of detection of Pseudogymnoascus destructans (Gargas et al., 2009; Minnis and Lindner, 2013).

Journal of Cave and Karst Studies, April 2016•45 


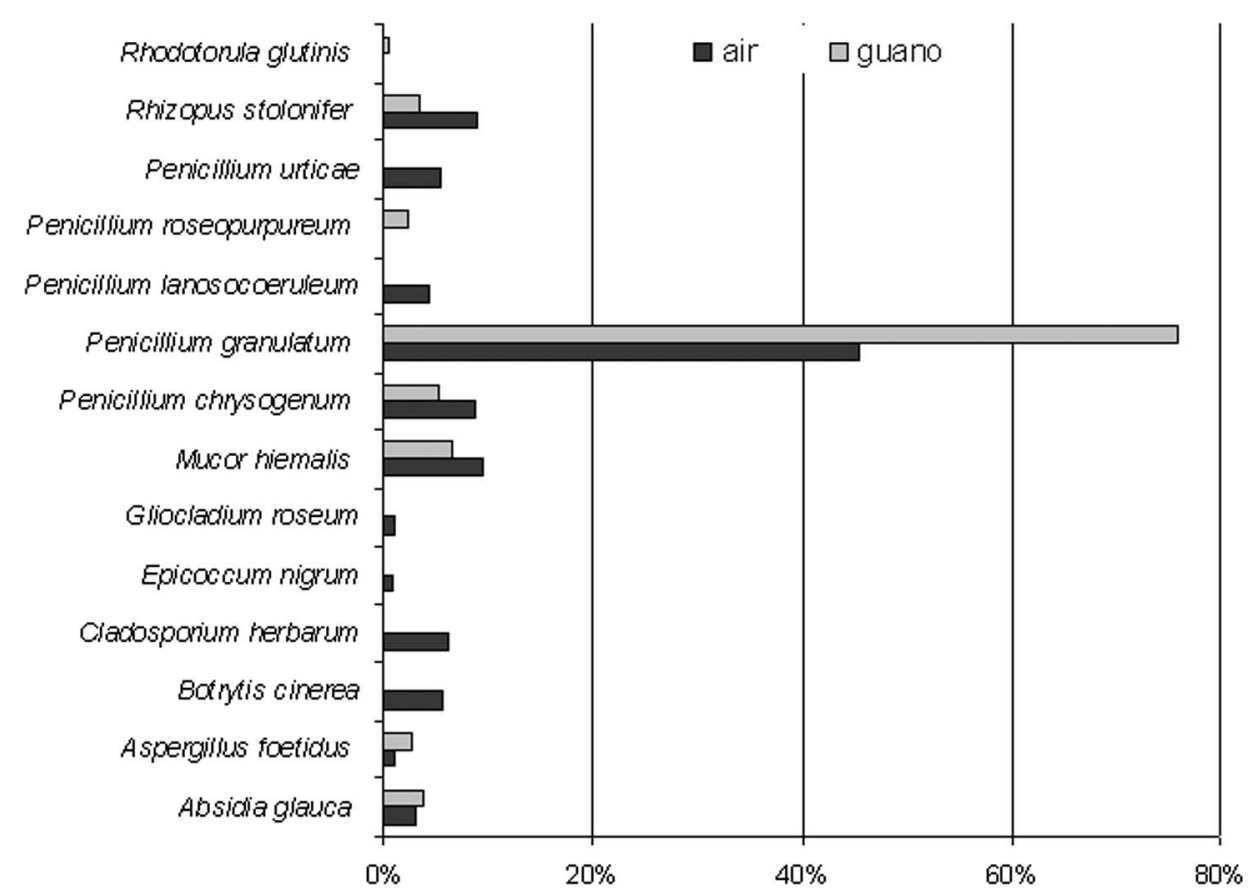

Figure 2. Relative percentages of colonies of filamentous fungi and yeast-like fungal species cultured from the bat guano and the air around it from Harmanecká Cave.

The most frequently isolated fungus from the guano and from the air collected in Harmanecká Cave and Driny Cave was Penicillium granulatum, with the exception of the guano collected in Driny Cave, where Mucor hiemalis was the most common. These species of fungi are common in many parts of the world. Their conidia and spores can be found in air, water, and soil and on animals and plants (Samson et al., 2011; Madden et al., 2012).
M. hiemalis may cause, for example, cutaneous and subcutaneous mucormycosis in humans belonging to the risk groups (Desai et al., 2013). P. granulatum may produce secondary metabolites, including mycotoxins, that are dangerous to animals and humans (Koteswara Rao et al., 2011). It can also cause allergic alveolitis, chronic respiratory symptoms, and sensitization by antigens from mold conidia (Qiu et al., 2014). Probably fungi such as

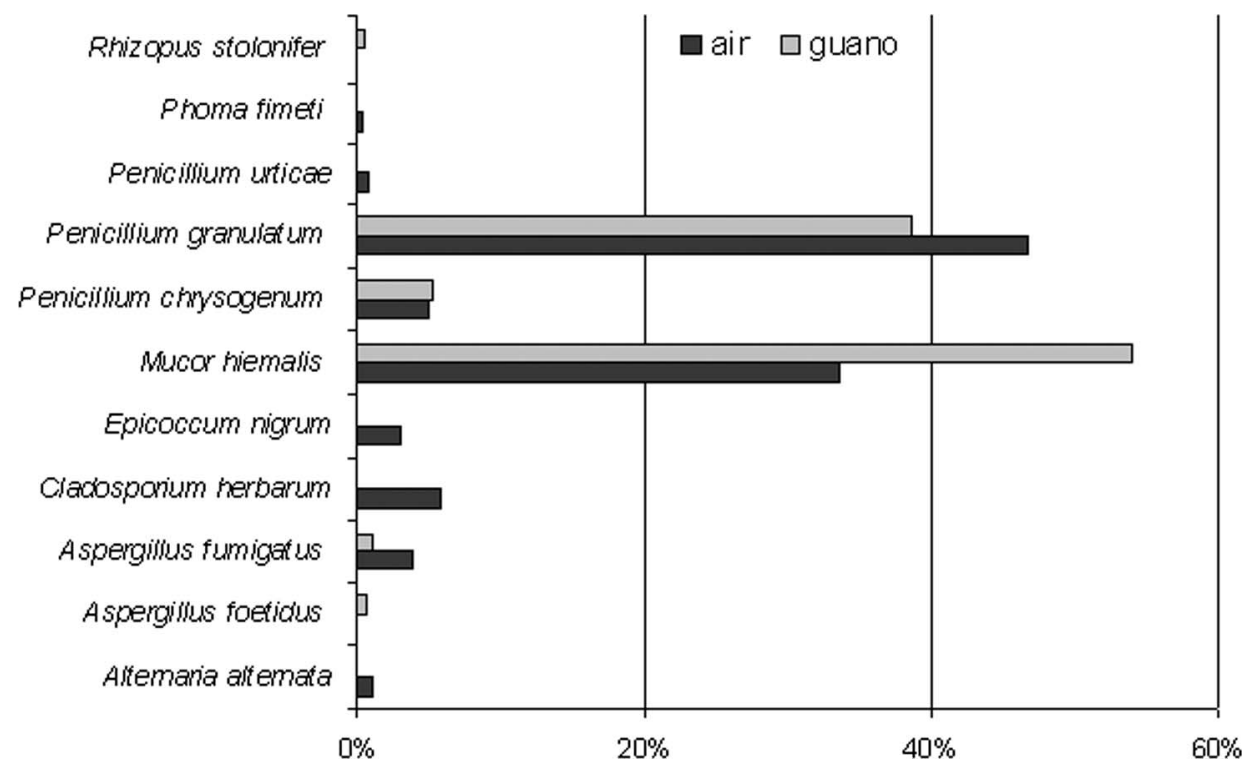

Figure 3. Relative percentages of colonies of filamentous fungal species cultured from the bat guano and the air around it in Driny Cave. 

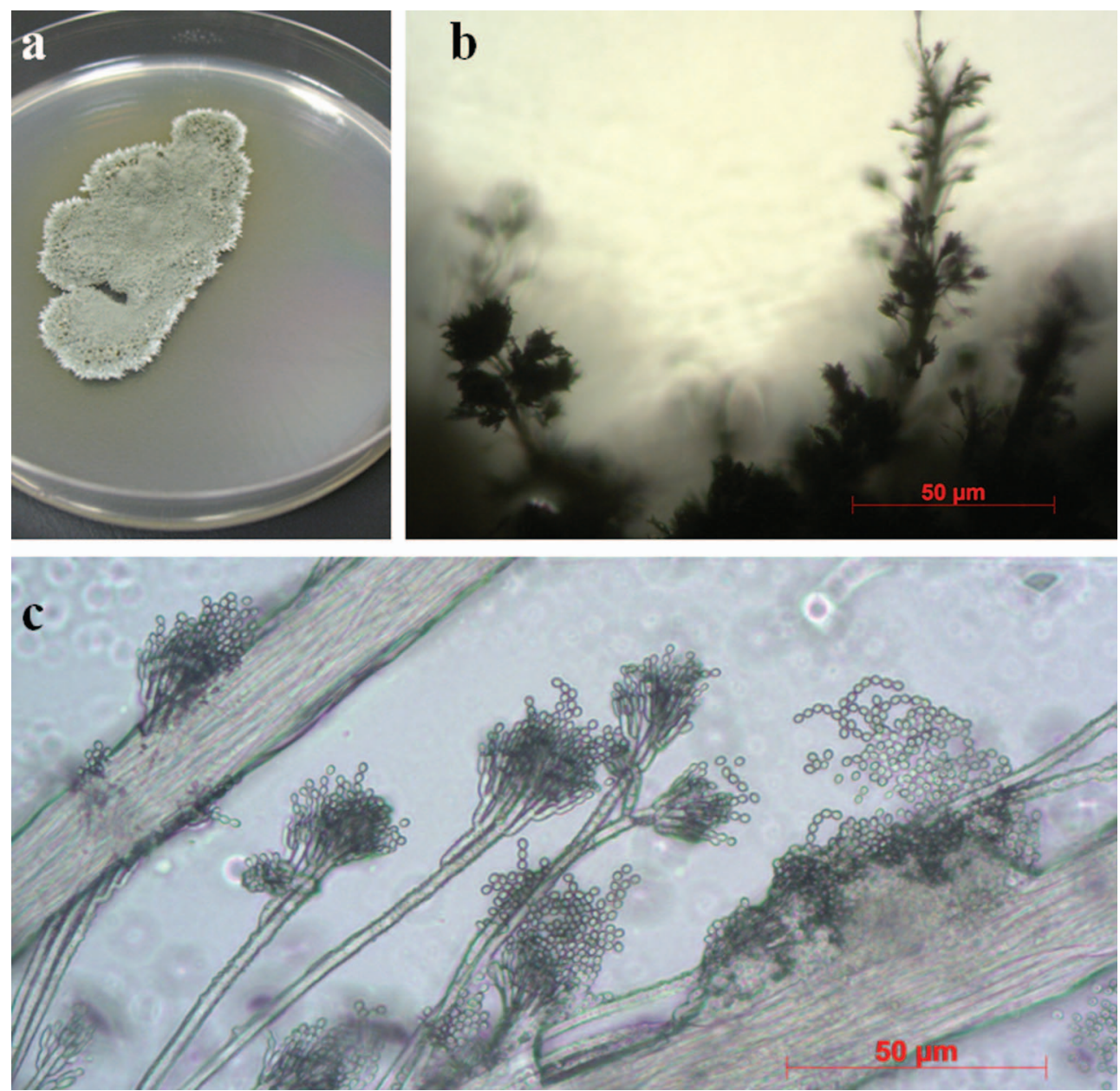

Figure 4. Penicillium granulatum culture on Potato Dextrose Agar medium, 10-day-old culture at $25{ }^{\circ} \mathrm{C}$ : a) top view of a colony; b) branched conidiophores under the optical microscope; c) branched conidiophores, phialides, and conidia under the optical microscope.

Penicillium spp. are also able to colonize membranes of hibernating bats. According to Johnson et al. (2013), fungi belonging to the Penicillium genus accounted for about $13 \%$ of all the strains isolated from hibernating bats. Nevertheless, the pathogenicity of species belonging to the Penicillium genus is controversial.

\section{Conclusions}

The results of the present study show that bat guano is a very good substrate for the development and survival of fungi inside caves, and it can also be a reservoir of fungi harmful to bats and humans. However, air samples from both caves contained more species of fungi than the bat guano, because the majority of fungi are transferred to underground ecosystems with bioaerosols from the external environment. Therefore, the external environment around an underground site and airflows are the major factors that affect the species composition and concentration of airborne fungi in indoor air of caves. The most frequently isolated species from the indoor and outdoor air and from the bat guano were fungi from the genus Penicillium (especially $P$. granulatum), except those isolated from guano of Driny Cave, where Mucor hiemalis was predominant. These fungi are common in many parts of the world. The observed concentrations and species composition of the fungi isolated from the air in both caves constitute no threat to the health of visiting tourists. We used only culture-based analysis of the fungal species, which did not allow us to detect nonculturable fungi. Therefore, in the near future, we are also going to use molecular techniques for in-depth characterization of environmental microbial communities in the case of underground mycobiota.

\section{ACKNOWLEDGEMENTS}

We would like to thank Dr. Ján Zuskin (director of Slovak Caves Administration) for his help in the study. This work was co-financed by the European Union as a part of the European Social Fund.

Journal of Cave and Karst Studies, April 2016•47 


\section{REFERENCES}

Barton, H.A., 2006, Introduction to cave microbiology: A review for the non-specialist: Journal of Cave and Karst Studies, v. 68, no. 2, p. 43-54.

Bastian, F., Jurado, V., Nováková, A., Alabouvette, C., and Saíz-Jiménez, C., 2010, The microbiology of Lascaux Cave: Microbiology, v. 156, no. 3, p. 644-652. doi:10.1099/mic.0.036160-0.

Bella, P., Hlavac, J., and Gazik, P., 2001, Protection and management of show caves in Slovakia: in Speleo Brazil 2001: 13th International Congress of Speleology, 4th Speleological Congress of Latin América and Caribbean, 26th Brazilian Congress of Speleology, Brasília, 15-22 July 2001, p. 287-290.

Blehert, D.S., Hicks, A.C., Behr, M., Meteyer, C.U., Berlowski-Zier, B.M., Buckles, E.L., Coleman, J.T.H., Darling, S.R., Gargas, A., Niver, R., Okoniewski, J.C., Rudd, R.J., and Stone, W.B., 2009, Bat white-nose syndrome: An emerging fungal pathogen?: Science, v. 323, no. 5911, p. 227. doi:10.1126/science. 1163874

Chelius, M.K, Beresford, G., Horton, H., Quirk, M., Selby, G., Simpson, R.T., Horrocks, R., and Moore, J.C., 2009: Impacts of alterations of organic inputs on the bacterial community within the sediments of Wind Cave, South Dakota, USA: International Journal of Speleology, v. 38, no. 1, p. 1-10. doi:10.5038/1827-806X.38.1.1.

Desai, R.P., Joseph, N.M., Ananthakrishnan, N., and Ambujam S., 2013, Subcutaneous zygomycosis caused by Mucor hiemalis in an immunocompetent patient: Australasian Medical Journal, v. 6, no. 7, p. 374-377. doi:10.4066/AMJ.2013.1764.

Gargas, A., Trest, M.T., Christensen, M., Volk, T.J., and Blehert D.S., 2009, Geomyces destructans sp. nov. associated with bat white-nose syndrome: Mycotaxon, v. 108, p. 147-154. doi:10.5248/108.147.

Griffin, D.W., Gray, M.A., Lyles, M.B., and Northup, D.E., 2014, The transport of nonindigenous microorganisms into caves by human visitation: A case study at Carlsbad Caverns National Park: Geomicrobiology Journal, v. 31, no. 3, p. 175-185. doi:10.1080/ 01490451.2013 .815294$.

Johnson, L.J.A.N., Miller, A.N., McCleery, R.A., McClanahan, R., Kath, J.A., Lueschow, S., and Porras-Alfaro, A., 2013, Psychrophilic and psychrotolerant fungi on bats and the presence of Geomyces spp. on bat wings prior to the arrival of white nose syndrome: Applied and Environmental Microbiology, v. 79, no. 18, p. 5465-5471. doi:10.1128/AEM.01429-13.

Kaufman, D.D., Williams, L.E., and Sumner, C.B., 1963, Effect of plating medium and incubation temperature on growth of fungi in soildilution plates: Canadian Journal of Microbiology, v. 9, no. 6, p. 741751. doi: $10.1139 / \mathrm{m} 63-100$

Koteswara Rao, V., Shilpa, P., Girisham, S., and Reddy, S.M., 2011, Incidence of mycotoxigenic penicillia in feeds of Andhra Pradesh, India: International Journal of Biotechnology and Molecular Biology Research, v. 2, no. 2, 46-50.

Kurtzman, C.P., Fell, J.W., and eds, 1998, The Yeasts, a Taxonomic Study, 4th ed.: Amsterdam, Elsevier, 1055 p.

Lehotská, B., Bačkor, P., Bobáková, L., Fulín, M., Lehotský, R., Matis, Š., Pjenčák, P., Uhrin, M., and Višňovská, Z., 2011, Zhrnutie poznatkov o netopieroch v sprístupnených jaskyniach na Slovensku (Summary of knowledge about bats in show caves in Slovakia): Aragonit, v. 16, no. 1, p.76-77.

Lehotská, B., and Lehotský, R., 2009, 15 rokov zimného monitoringu netopierov v jaskyni Driny ( 15 years of winter monitoring of bats in the Driny Cave): Aragonit, v. 14, no. 2, p. 171-172.

Littman, M.L., 1947, A culture medium for the primary isolation of fungi: Science, v. 106, no. 2744, p. 109-111. doi:10.1126/science. 106.2744.109-a.

Madden, A.A., Stchigel, A.M., Guarro, J., Sutton, D., and Starks, P.T., 2012, Mucor nidicola sp. nov., a fungal species isolated from an invasive paper wasp nest: International Journal of Systematic and Evolutionary Microbiology, v. 62, p. 1710-1714. doi:10.1099/ ijs. $0.033050-0$.

Macher, J.M., 2001, Review of methods to collect settled dust and isolate culturable microorganisms: Indoor Air, v. 11, no. 2, p. 99-110. doi:10.1034/j.1600-0668.2001.110204.x.

MacNeil, L., Kauri, T., and Robertson, W., 1995, Molecular techniques and their potential application in monitoring the microbiological quality of indoor air: Canadian Journal of Microbiology, v. 41, p. 657-675. doi:10.1139/m95-091.
Marshall, V., Poulson-Cook, S., and Moldenhauer, J. 1998, Comparative mold and yeast recovery analysis (the effect of differing incubation temperature ranges and growth media): PDA Journal of Pharmaceutical Science and Technology, v. 52, no. 4, p. 165-169.

Meletiadis, J., Meis, J.F.G.M., Mouton, J.W., and Verweij, P.E., 2001, Analysis of growth characteristics of filamentous fungi in different nutrient media: Journal of Clinical Microbiology, v. 39, no. 2, p. 478 484. doi:10.1128/JCM.39.2.478-484.2001.

Minnis, A.M., and Lindner, D.L., 2013, Phylogenetic evaluation of Geomyces and allies reveals no close relatives of Pseudogymnoascus destructans, comb. nov., in bat hibernacula of eastern North America: Fungal Biology, v. 117, p. 638-649. doi:10.1016/j.funbio.2013. 07.001 .

Mulec, J., 2008, Microorganisms in hypogen: examples from Slovenian karst caves: Acta Carsologica, v. 37, no. 1, p. 153-160. doi:10.3986/ ac.v37i1.167.

Mulec, J., Covington, E., and Walochnik, J., 2013, Is bat guano a reservoir of Geomyces destructans?: Open Journal of Veterinary Medicine, v. 3, no. 2, p. 161-167. doi:10.4236/ ojvm.2013.32025.

Nieves-Rivera, Á.M., Santos-Flores, C.J., Dugan, F.M. and Miller, T.E., 2009, Guanophilic fungi in three caves of southwestern Puerto Rico: International Journal of Speleology, v. 38, no. 1, p. 61-70. doi:10.5038/1827-806X.38.1.7.

Nováková, A., 2009, Microscopic fungi isolated from the Domica Cave system (Slovak Karst National Park, Slovakia). A review: International Journal of Speleology, v. 38, no. 1, p. 71-82. doi:10.5038/1827806X.38.1.8.

Ogórek, R., Kalinowska, K., Pląskowska, E., Baran, E., and Moszczyńska, E., 2011a, Zanieczyszczenia powietrza grzybami na różnych podłożach hodowlanych $\mathrm{w}$ wybranych pomieszczeniach kliniki dermatologicznej. Część 1 (Mycological air pollutions on different culture mediums in selected rooms of dermatology department. Part I): Mikologia Lekarska, v. 18, no. 1, p. 30-38.

Ogórek, R., Kalinowska, K., Pląskowska, E., Baran, E., and Matkowski, K., 2011b, Zanieczyszczenia powietrza grzybami na różnych podłożach hodowlanych $\mathrm{w}$ wybranych pomieszczeniach kliniki dermatologicznej. Część 2 (Mycological air pollutions on different culture mediums in selected rooms of dermatology department. Part II); Mikologia Lekarska, v. 18, no. 2, p. 79-86.

Ogórek, R., Lejman, A., and Matkowski, K., 2013, Fungi isolated from the Niedźwiedzia Cave in Kletno (Lower Silesia, Poland): International Journal of Speleology, v. 42, no. 2, p. 161-166. doi:10.5038/ 1827-806X.42.2.9.

Ogórek, R., Lejman, A., and Matkowski, K., 2014a, Influence of the external environment on airborne fungi isolated from a cave: Polish Journal of Environmental Studies, v. 23, no. 2, p. 435-440.

Ogórek, R., Pusz, W., Lejman, A., Uklańska-Pusz C., 2014b, Microclimate effects on number and distribution of fungi in the Włodarz underground complex in the Owl mountains (Góry Sowie), Poland: Journal of Cave and Karst Studies, v. 76, no. 2, p. 146-153. doi:10.4311/2013MB0123.

Ogórek, R., Pusz, W., Matkowski, K., Pląskowska E., 2014c, Assessment of abundance and species composition of filamentous fungi in the underground Rzeczka complex in Sowie Mountains (Lower Silesia, Poland): Geomicrobiology Journal, v. 31, no. 10, p. 900-906. doi:10.1080/01490451.2014.907380.

Pasanen, A.-L., 2001, A review: Fungal exposure assessment in indoor environments: Indoor Air, v. 11, no. 2, p. 87-98. doi:10.1034/j.16000668.2001.110203.x.

Pitt, J.I., and Hocking, A.D., 2009, Fungi and Food Spoilage, 3rd edition: New York, Springer, $519 \mathrm{p}$.

Poulson, T.L., and Lavoie, K.H., 2000, The trophic basis of subsurface ecosystems, in Wilkins, H., Culver, D.C., and Humphreys, W.F., eds., Subterranean Ecosystems: Amsterdam, Elsevier Press, Ecosystems of the World 30, p. 231-249.

Pusz, W., Ogórek, R., Uklańska-Pusz, C.M., Zagożdżon P., 2014, Speleomycological research in underground Osówka complex in Sowie Mountains (Lower Silesia, Poland): International Journal of Speleology, v. 43, no. 1, p. 27-34. doi:10.5038/1827-806X.43.1.3.

Qiu, Ye, Zhang, Jianquan, Liu, Guangnan, Zhong, Xiaoning, Deng, Jingmin, He, Zhiyl, and Jing, Bai, 2014, A case of Penicillium marneffei infection involving the main tracheal structure: BMC Infectious Diseases, v. 14, p. 1-6. doi:10.1186/1471-2334-14-242. 
Rastogi, G., and Sani, R.K., 2011, Molecular techniques to assess microbial community structure, function, and dynamics in the environment, in Ahmad, I., Ahmed, F., and Pichtel, J., eds., Microbes and Microbial Technology: Agricultural and Environmental Applications: New York, Springer Science \& Business Media, p. 29-57. doi:10.1007/978-1-4419-7931-5_2.

Samson, R.A., Yilmaz, N., Houbraken, J., Spierenburg, H., Seifert, K.A., Peterson, S.W., Varga, J., and Frisvad, J.C., 2011, Phylogeny and nomenclature of the genus Talaromyces and taxa accommodated in Penicillium subgenus Biverticillium: Studies in Mycology, v.70, p. 159-183. doi:10.3114/sim.2011.70.04.

Shetty, S., Sreepada, K.S., and Bhat, R., 2013, Effect of bat guano on the growth of Vigna radiata L: International Journal of Scientific and Research Publications, v. 3, no. 3, 8 p.

Smith, D., 1988, Culture and preservation, in Hawksworth, D.L., and Kirsop, B.E., eds., Filamentous Fungi: Cambridge Cambridge University Press, Living Resources for Biotechnology series, p. 75-99.

Šustr, V., Elhottová, D., Krištůfek, V., Lukešová, A., Nováková, A., Tajovský, K., and Tř́ska, J., 2005, Ecophysiology of the cave isopod Mesoniscus graniger (Frivaldszky 1865) (Crustacea: Isopoda): European Journal of Soil Biology, v. 41, no. 3-4, p. 69-75. doi:10.1016/ j.ejsobi.2005.09.008.
Vanderwolf, K.J., Malloch, D., McAlpine, D.F., and Forbes, G.J., 2013, A world review of fungi, yeasts, and slime molds in caves: International Journal of Speleology, v. 42, no. 1, p. 77-96. doi:10.5038/1827-806X.42.1.9.

Verant, M.L., Boyles, J.G., Waldrep, W. Jr., Wibbelt, G., and Blehert, D.S. 2012, Temperature-dependent growth of Geomyces destructans, the fungus that causes bat White-Nose Syndrome: PLOS ONE, v. 7, no. 9, e46280, 7 p. doi:10.1371/journal.pone.0046280.

Walochnik, J., and Mulec, J., 2009, Free-living amoebae in carbonate precipitating microhabitats of karst caves and a new vahlkampfiid amoeba, Allovahlkampfia spelaea gen. nov., sp. nov.: Acta Protozoologica, v. 48 , no. 1 , p. $25-33$.

Watanabe, T., 2010, Pictorial Atlas of Soil and Seed Fungi: Morphologies of Cultured Fungi and Key to Species, third edition: Boca Raton, Florida, CRC press, $404 \mathrm{p}$.

World Health Organization, 1990, Indoor Air Quality: Biological Contaminants: Report on a WHO Meeting, Rautavaara, 29 August-2 September 1988: Copenhagan, WHO Regional Office for Europe, WHO Regional Publications European Series 31, 67 p.

Wu, Pei-Chih, Su, Huey-Jen., and Ho, Hsiao-Man, 2000, A comparison of sampling media for environmental viable fungi collected in a hospital environment: Environmental Research, v. 82, no. 3, p. 253-257. doi:10.1006/enrs.1999.4017. 